\title{
Maternal Health Education (Pregnant, Childbirth and Postpartum Periods) during the COVID-19 Pandemic: Literature Review
}

\author{
Suryani Manurung ${ }^{1}$ \\ Jakarta Health Ministry Polytechnic 1, Indonesia \\ E-mail: yani_manru@yahoo.co.id
}

\begin{abstract}
Maternal is the condition of the mother during pregnancy, childbirth, and puerperal. One of the susceptible individuals infected with COVID-19 is maternal. This condition causes the mother to worry both herself and the baby, so these problems need to be identified and prevented through health education. This article aimed to identify problems and maternal health education (pregnancy, childbirth, and puerperal) during the COVID-19 pandemic. The data collected through an online portal that is PubMed, the Jakarta Health Polytechnic I ProQuest, Google Scholar, and Google-based website. Keywords used to search for information related to the topics discussed are the epidemiology of SARS-COV-2, pregnancy, childbirth, and puerperal during the COVID-19 period, the maternal immune system, complaints, and maternal questions of the COVID-19 pandemic period, and prevention of COVID-19 infection on maternal. The results found a risk of COVID-19 infection in the maternal in the amount of 4.9/1000 pregnant women. Based on COVID-19 infections from nine infected, seven were found dead, and two were surviving. Maternal infection during pregnancy has complications, including fetal distress (2 cases), membrane rupture ( 2 cases), preeclampsia ( 1 case), is a factor in preterm labor, mature delivery (1 person). In conclusion, maternal is a high-risk group for exposure to infection. The risk of vertical infection of the mother to the baby has not been proven. Maternal requires information on prevention and care during pregnancy, childbirth, and the puerperal.
\end{abstract}

Keywords: COVID-19 pandemic, health education, maternal 


\section{Introduction}

The infectious disease caused by COVID-19 has become pandemic as it has spread rapidly throughout the world. As of May 12, 2020, COVID-19 infections globally totaled $4,868,848$ cases, with 82,951 new cases and 283,153 deaths. ${ }^{1}$ In Indonesia, total COVID-19 infections as of May 12, 2020, reached 14.265 individuals, of whom 239 died. ${ }^{1}$ The infections have most commonly affected a certain group of vulnerable individuals, namely the elderly and those who have chronic diseases. ${ }^{1}$ However, other individuals vulnerable to the infections also include pregnant, giving birth, and puerperal women (the maternal). However, other individuals vulnerable to the infections also include pregnant, giving birth, and puerperal women (the maternal) considering that Indonesia is one of the countries that had maternal and infant mortality incidents that occurred before the COVID-19 pandemic. Likely, this will also increase at this time. ${ }^{2,3}$

Before the COVID-19 pandemic, the maternal mortality rate in Indonesia was already high, specifically, 305/100,000 live births $(\mathrm{KH}){ }^{4}$ Based on the information acquired, incidents of maternal mortality and morbidity in Iran due to severe infection with COVID-19 with nucleate acid testing rTT-PCR (NAT) overrode nine people. These pregnant women were in the second and third trimesters. ${ }^{2}$ At the time of reporting, seven individuals were found dead, one critically ill and dependent on a ventilator, and another person recovered after being hospitalized for a long time. ${ }^{2}$ In the UK, maternal cases infected with COVID-19 from 1 March to 14 April 2020 were as many as 4.9 pregnant women per 1,000 people hospitalized, where around 110 of them were treated in intensive care. ${ }^{5}$ Incidents of maternal COVID-19 infection in Indonesia have not been officially recorded and reported. However, social media and online newspapers have asserted that there have been 39 pregnant women exposed to COVID-19 infections in the country. Based on the questions and answers collected by the Royal College of Obstetricians and Gynecologists (2020) and WHO (2020b) related to pregnancy, childbirth, and the puerperium, this situation has induced a sense of fear, worry for mothers both abroad and in Indonesia. This concern has arisen because two beings must be saved, namely the mothers and their babies. ${ }^{4}$

Based on a review of maternal questions and complaints about the risk of COVID-19 infection, the maternal group generally has yet to understand specific information related to COVID-19 infection, where this has made them fear and worried. This information covers the risk of 
infection to the fetus and neonate, type of childbirth, touch behavior in babies, lactation process, and efforts to control the risk of infection in maternal women and babies. The lack of understanding of the information suggests the need to provide maternal education during the prenatal period. Education about these matters is expected to improve infection prevention behavior in maternal and fetus/infants and improve the maternal psychological health so they can survive the COVID-19 pandemic.

\section{Method}

Information Sources and Strategies

The source of information is secondary data. Data were collected through an online portal that is PubMed, ProQuest Health Polytechnic Jakarta I, google scholar, and coupled through a google search-based websites, websites of organizations, and online media. Information search is done by writing the keyword that is the epidemiology of SARS-CoV-2, pregnancy, childbirth, post-natal period COVID-19, complaints and questions pregnant women, childbirth, the postpartum period COVID19 pandemic and prevention of infection COVID-19 on the maternal. Data were collected from May 1-June 5, 2020.
Search data using the portal from PubMed, Jakarta Health Polytechnic ProQuest I, there are five Google Scholar and added from a search using Googlebased website 10 articles. Total articles obtained before selection according to inclusion and exclusion criteria were 15 articles. Articles on the same topic were found five then the data is removed.

\section{Data Analysis Process}

The data have been collected under the

inclusion criteria were analyzed. An analysis is done by reading the contents of the article. Information is then selected based on the objectives to be explained, namely, the risk of COVID-19 for maternal and information are needed by the maternal during the COVID-19 pandemic. The selection process is carried out on each information then establishes the information used. Therefore, the data collected following the purpose of writing is as much as eight articles. Then performed a meta-analysis of the information that has been selected. Following the flow of the data collection method can be presented in Figure 1.

\section{Data Selection Process}




\section{Results}

Based on the description of all patients in the study case, the patient's condition is in the second and third trimesters. Results of a meta-analysis of case studies from several countries and needs assessment information to COVID-19 informed that maternal conditions were infected with SARS-CoV2 at risk of death and healing accompanied by comorbidities. Likewise, babies are born prematurely with spontaneous vaginal delivery or cesarean section, the SARS-CoV2 test in infants is negative. The risk of maternal and fetal COVID-19 exposure raises several questions and complaints from mothers. This information has been reported in tables 1 and 2.

\section{Results}

Based on the description of all patients in the study case, the patient's condition is in the second and third trimesters. Results of a meta-analysis of case studies from several countries and needs assessment information to COVID-19 informed that maternal conditions were infected with SARS-COV2 at risk of death and healing accompanied by comorbidities. Likewise, babies are born prematurely with spontaneous vaginal delivery or cesarean section, the SARS-COV2 test in infants is negative. The risk of maternal and fetal COVID-19 exposure raises several questions and complaints from mothers.

Table 1 Results of a meta-analysis of all cases illustrate that the risk of a mother infected with COVID-19 is not evidenced by exposure to infection in newborns, spontaneous births pervaginal, and born with cesarean section and disability. But it affects the birth of premature babies and low birth weight. Meta-analysis results illustrate that neonatal deaths are caused by complications of pregnancy and age prematurely. The risk of maternal COVID19 infection is death, pregnancy complications such as premature rupture of membranes, and preeclampsia. The severity of the risk of COVID-19 infection in both mothers and infants is also expressed by maternal through complaints and questions related to prevention, maternal care, fetus/baby during the COVID-19 pandemic. 


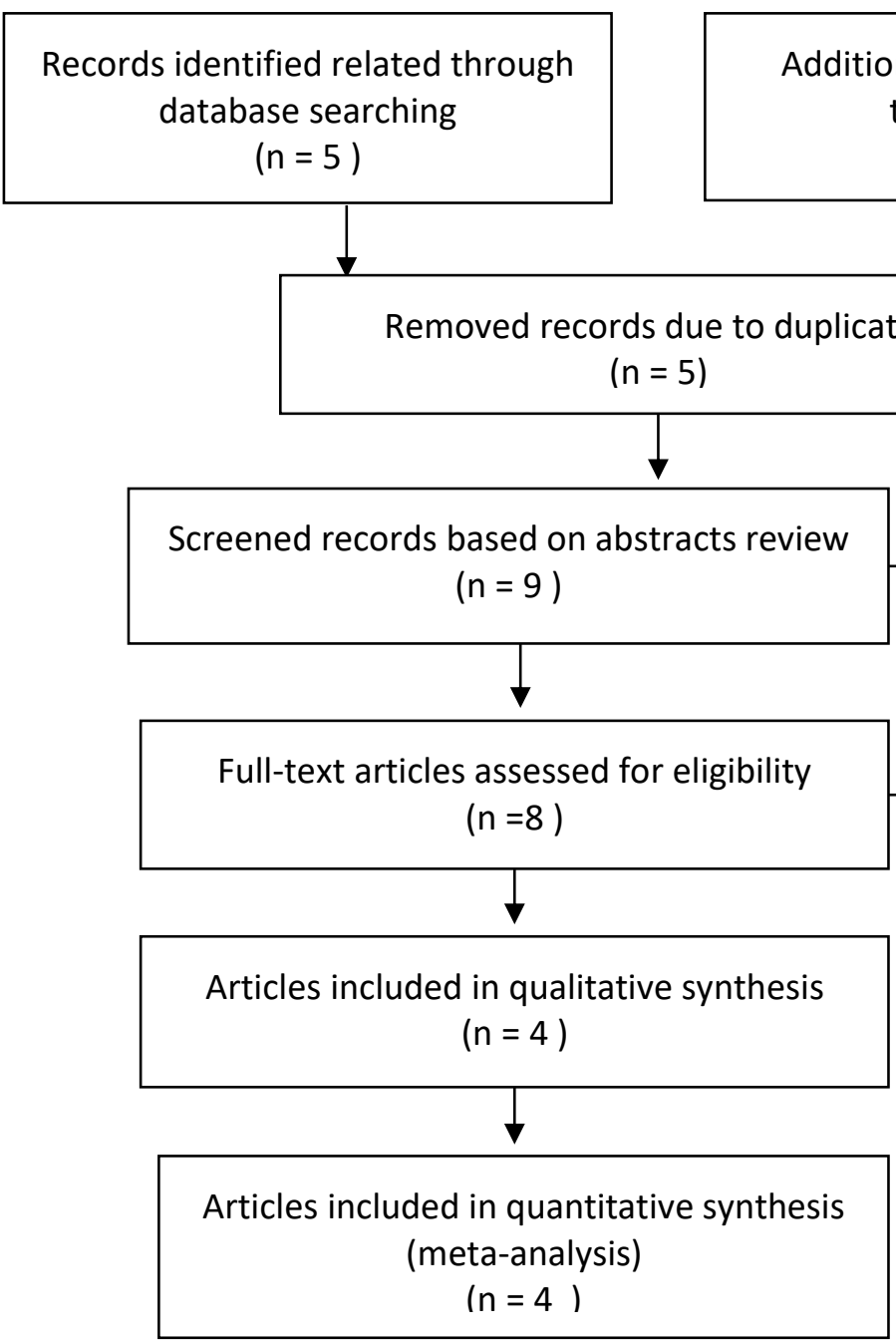

Additional records identified related through other sources $(\mathrm{n}=10)$

Figure 1. PRISMA flow diagram of the articles selection process

Table 1. Results of a meta-analysis of the conditions of the mother, fetus, type of labor, and neonatal with SARS-CoV-2 positive in several countries during the COVID-19 pandemic in 2020.

\begin{tabular}{|c|c|c|c|c|c|c|}
\hline Author & Title & $\begin{array}{c}\text { Year of } \\
\text { published }\end{array}$ & Country & $\begin{array}{c}\text { Research } \\
\text { design }\end{array}$ & sample & Results \\
\hline $\begin{array}{l}\text { Author } 1 \\
\text { Hantoushzadeh S, } \\
\text { et.al (2020) }\end{array}$ & $\begin{array}{l}\text { Maternal } \\
\text { Death Due to } \\
\text { COVID-19 } \\
\text { Disease }\end{array}$ & 2020 & Iran & $\begin{array}{l}\text { retrospective } \\
\text { case series }\end{array}$ & 9 cases & $\begin{array}{l}\text { Current maternal } \\
\text { conditions are } \\
\text { observed: } \\
\text { - Pregnant phase } \\
\text { with the preterm } \\
\text { condition, } \\
\text { gestational age }\end{array}$ \\
\hline
\end{tabular}

(C) Jurusan Keperawatan Poltekkes Kemenkes Jakarta I

Jl. Wijaya Kusuma No. 47-48 Cilandak Jakarta Selatan, Indonesia

Email: jurnalkpcardio@gmail.com 
24-36 weeks of seven cases and mature with gestational age 37-39 weeks two cases.Gestational age: preterm (2436 weeks) 7 cases and mature 37-39 Week two cases.

- Mother died with acute respiratory distress syndrome (ARDS) amounted to seven cases and survive with gestational age 37-39 weeks amounting to two cases.

Delivery Type:

- labor with cesarean section is six

- pervagina spontaneous labor is one.

- Labor with preterm premature rupture of membranes (PPROM) is fone.

Baby's condition when observed:

- Baby dies after birth is one (PPROM)

- Babies born with intrauterine Fetus Death (IUFD) amounts to four.

- Babies are not born with the condition of intra-uterine Fetus Death (IUFD) amounts to two (the condition of the mother died).

- Babies born with the condition live, healthyCOV2 SARS test 
results negative amounting to two

\begin{tabular}{|c|c|c|c|c|c|c|}
\hline \multirow[t]{3}{*}{$\begin{array}{l}\text { Author } 2 \\
\text { Knight } \mathrm{M} \text {, et all }\end{array}$} & \multirow[t]{3}{*}{$\begin{array}{l}\text { Characteristics } \\
\text { and outcomes } \\
\text { of pregnant } \\
\text { women } \\
\text { admitted to } \\
\text { hospital with } \\
\text { confirmed } \\
\text { SARS-CoV-2 } \\
\text { infection in } \\
\text { the UK: } \\
\text { national } \\
\text { population- } \\
\text { based cohort } \\
\text { study }\end{array}$} & \multirow[t]{3}{*}{2020} & \multirow[t]{3}{*}{ UK } & \multirow[t]{3}{*}{$\begin{array}{l}\text { observational } \\
\text { study }\end{array}$} & \multirow[t]{3}{*}{$\begin{array}{l}427 \\
\text { respond } \\
\text { en }\end{array}$} & $\begin{array}{l}\text { Maternal conditions } \\
\text { when observed: } \\
\text { - pregnant with } \\
\text { gestational age: } \\
\text { premature 22-36 } \\
\text { weeks totaling } \\
\text { 252; Mature } \geq 37 \\
\text { weeks amounted to } \\
142 \text {. } \\
\text { - Comorbidities } \\
\text { were found, } \\
\text { asthma, } \\
\text { hypertension, heart } \\
\text { disease, diabetes. }\end{array}$ \\
\hline & & & & & & $\begin{array}{l}\text { Peripartum phase } \\
\text { (labor and delivery) } \\
\text { amounted to } 30\end{array}$ \\
\hline & & & & & & $\begin{array}{l}\text { The final result of } \\
\text { observation: } \\
\text { - Maternal who died } \\
\text { of five, } \\
\text { - Maternal return to } \\
\text { healthy conditions } \\
\text { amounted to } 397 \text {, } \\
\text { - Maternal still } \\
\text { being treated } \\
\text { amounted to } 25 \text {. }\end{array}$ \\
\hline $\begin{array}{l}\text { Author } 3 \\
\text { Khan S, et all }\end{array}$ & $\begin{array}{l}\text { Impact of } \\
\text { COVID-19 } \\
\text { infection on } \\
\text { pregnancy } \\
\text { outcomes and } \\
\text { the risk of } \\
\text { maternal-to- } \\
\text { neonatal } \\
\text { intrapartum } \\
\text { transmission } \\
\text { of COVID-19 } \\
\text { during natural } \\
\text { birth }\end{array}$ & 2020 & China & $\begin{array}{l}\text { Prospective } \\
\text { studi }\end{array}$ & 3 cases & $\begin{array}{l}\text { Mother's condition } \\
\text { when observed: } \\
\text { Premature } \\
\text { pregnancy (34-35) } \\
\text { in one case and } \\
\text { mature pregnancy } \\
\text { (38-39 weeks) in } \\
\text { two cases. } \\
\text { Delivery Type: } \\
\text { Pervagina } \\
\text { spontaneous } \\
\text { labor as much as } \\
\text { three. }\end{array}$ \\
\hline & & & & & & $\begin{array}{l}\text { Baby's condition at } \\
\text { birth: } \\
\text { - The baby was } \\
\text { born healthy, the } \\
\text { negative SARS- } \\
\text { COV2 test } \\
\text { numbered three }\end{array}$ \\
\hline
\end{tabular}




\section{- Babies born with a weight of 2890 grams to $3730 \mathrm{gr}$}

\begin{tabular}{|c|c|c|c|c|c|c|}
\hline $\begin{array}{l}\text { Author } 4 \\
\text { Chen H, et all }\end{array}$ & $\begin{array}{l}\text { Clinical } \\
\text { characteristics } \\
\text { and } \\
\text { intrauterine } \\
\text { vertical } \\
\text { transmission } \\
\text { potential of } \\
\text { COVID-19 } \\
\text { infection in } \\
\text { nine pregnant } \\
\text { women }\end{array}$ & 2020 & Wuhan & Retrospective & $\begin{array}{l}9 \\
\text { respond } \\
\text { en }\end{array}$ & $\begin{array}{l}\text { Mother's condition } \\
\text { when observed: } \\
\text { - A pregnant phase } \\
\text { is premature with } \\
36 \text { weeks } \\
\text { gestation and } \\
\text { mature with 37- } \\
39 \text { weeks } \\
\text { gestation } \\
\text { - Symptoms of } \\
\text { COVID-19 } \\
\text { infection } \\
\text { experienced by } \\
\text { mothers the same } \\
\text { as those who are } \\
\text { not pregnant. } \\
\text { - Pregnancy } \\
\text { complications } \\
\text { experienced are } \\
\text { fetal distress, } \\
\text { membrane } \\
\text { rupture, } \\
\text { preeclampsia (36 } \\
\text { weeks' } \\
\text { gestation). } \\
\\
\text { Labor risks: } \\
\text { Preterm labor } \\
\text { with vaginal } \\
\text { delivery } \\
\text { Baby's condition at } \\
\text { birth: } \\
\text { Babies born without } \\
\text { defects, low birth } \\
\text { weight, fit } \\
\text { conditions, negative } \\
\text { SARS-COV2 test. }\end{array}$ \\
\hline $\begin{array}{l}\text { Author } 5 \\
\text { WHO }(2020)^{9}\end{array}$ & $\begin{array}{l}\text { Maternal } \\
\text { questions } \\
\text { about COVID- } \\
19\end{array}$ & 2020 & Indonesia & WA & NA & $\begin{array}{l}\text { Information about } \\
\text { the Impact of } \\
\text { COVID-19 } \\
\text { Pregnancy } \\
\text { Information about } \\
\text { the Impact of } \\
\text { COVID-19 } \\
\text { Childbirth } \\
\text { information about } \\
\text { the Impact of } \\
\text { COVID-19 } \\
\text { Postpartum Mothers } \\
\text { and neonates. }\end{array}$ \\
\hline
\end{tabular}




\begin{tabular}{|c|c|c|c|c|c|c|}
\hline $\begin{array}{l}\text { Author } 6 \\
\text { Hollier }(2020)^{10}\end{array}$ & $\begin{array}{l}\text { Coronavirus } \\
\text { (COVID-19), } \\
\text { Pregnancy, } \\
\text { and } \\
\text { Breastfeeding: } \\
\text { A Message for } \\
\text { Patients }\end{array}$ & 2020 & USA & Telehealth & NA & $\begin{array}{l}\text { Information about } \\
\text { the Impact of } \\
\text { COVID-19 } \\
\text { Pregnancy } \\
\text { Information about } \\
\text { the Impact of } \\
\text { COVID-19 } \\
\text { Childbirth } \\
\text { information about } \\
\text { the Impact of } \\
\text { COVID-19 } \\
\text { Postpartum Mothers } \\
\text { and neonates. }\end{array}$ \\
\hline $\begin{array}{l}\text { Author } 7 \\
\text { RCOG }(2020)^{(11)}\end{array}$ & $\begin{array}{l}\text { Coronavirus } \\
\text { infection and } \\
\text { pregnancy }\end{array}$ & 2020 & London & Telehealth & NA & $\begin{array}{l}\text { Information about } \\
\text { the Impact of } \\
\text { COVID-19 } \\
\text { Pregnancy } \\
\text { Information about } \\
\text { the Impact of } \\
\text { COVID-19 } \\
\text { Childbirth } \\
\text { information about } \\
\text { the Impact of } \\
\text { COVID-19 } \\
\text { Postpartum Mothers } \\
\text { and neonates. }\end{array}$ \\
\hline $\begin{array}{l}\text { Author } 8 \\
\text { World Health } \\
\text { Organization } \\
(\text { WHO) }(2020)\end{array}$ & $\begin{array}{l}\text { Q\&A } \\
\text { Pregnancy, } \\
\text { childbirth, and } \\
\text { COVID-19 }\end{array}$ & 2020 & N.A & Telehealth & NA & $\begin{array}{l}\text { Information about } \\
\text { the Impact of } \\
\text { COVID-19 } \\
\text { Pregnancy } \\
\text { Information about } \\
\text { the Impact of } \\
\text { COVID-19 } \\
\text { Childbirth } \\
\text { information about } \\
\text { the Impact of } \\
\text { COVID-19 } \\
\text { Postpartum Mothers } \\
\text { and neonates. }\end{array}$ \\
\hline
\end{tabular}

Table 2. Summary of findings in the study of information needs about the impact of COVID-19 on pregnancy, childbirth, postpartum, and neonates.

\begin{tabular}{|c|c|c|c|c|c|c|c|c|}
\hline $\begin{array}{l}\text { Information about the } \\
\text { impact of COVID-19 }\end{array}$ & Author 1 & Author 2 & Author 3 & Author 4 & $\begin{array}{c}\text { WHO } \\
(2020)^{9} \\
5\end{array}$ & $\begin{array}{c}\text { Hollier } \\
(2020)^{10} \\
6\end{array}$ & $\begin{array}{c}\text { RCOG } \\
(2020)^{11} \\
7\end{array}$ & $\begin{array}{c}\text { World } \\
\text { Health } \\
\text { Organisati } \\
\text { on, } \\
(2020)^{12} 8\end{array}$ \\
\hline
\end{tabular}

\section{In Pregnancy}

Risk of transmission

$\sqrt{ }$

V

V

$\checkmark$

$\checkmark$

V

V

$\checkmark$

mother

(C) Jurusan Keperawatan Poltekkes Kemenkes Jakarta I

Jl. Wijaya Kusuma No. 47-48 Cilandak Jakarta Selatan, Indonesia

Email: jurnalkpcardio@gmail.com 
Efforts to protect themselves from COVID-19

Examination needed to detect COVID-19

Risk of COVID-19 transmission to the fetus

\section{In Childbirth}

Information about the Impact of COVID-19 Childbirth and neonate.

Care that is needed in the face of childbirth

The right type of labor is surgery or vaginal delivery

If the baby is born, they still need early contact and breastfeeding.

Risk of transmission from mother to baby during pregnancy or after birth.
$\mathrm{Na}$

$\mathrm{Na}$

$\mathrm{Na}$

$\mathrm{Na}$

V

V

V

v

v v

v

V

V

\section{V}

$$
\text { v }
$$

v

v $\quad$ v

v

V

V

$\mathrm{Na}$

$\mathrm{Na}$

$\mathrm{Na}$

$\mathrm{Na}$

$\mathrm{Na}$

$\mathrm{Na}$

$\mathrm{Na}$

$\mathrm{Na}$

v

v

V

V

$\mathrm{Na}$

$\mathrm{Na}$

$\mathrm{Na}$

V

v v

V

v

V

v

V

V

V

V

\section{In Postpartum and}

Neonates

The need to

$\mathrm{Na}$

$\mathrm{Na}$

$\mathrm{Na}$

$\mathrm{Na}$

V

V

V

v

breastfeed should be

given or not safety in

breastfeeding if the

mother is

suspected/infected

COVID-19

Infants who are

$\mathrm{Na}$

$\mathrm{Na}$

$\mathrm{Na}$

$\mathrm{Na}$

V

v

V

V

touched and held,

what is the risk of

being infected with

COVID-19

What can I do if

$\mathrm{Na}$

$\mathrm{Na}$

$\mathrm{Na}$

$\mathrm{Na}$

v

v

exposed to COVID-

19 infection

associated with

breastfeeding

Infected mothers

$\mathrm{Na}$

$\mathrm{Na}$

$\mathrm{Na}$

$\mathrm{Na}$

V

COVID-19, whether

to breastfeed

I was exposed to

$\mathrm{Na}$

$\mathrm{Na}$

$\mathrm{Na}$

$\mathrm{Na}$

v

v

V

v

-

hold the baby

The process of

$\mathrm{Na}$

$\mathrm{Na}$

$\mathrm{Na}$

$\mathrm{Na}$

v

V

V

v

breast milk COVID-

19.

I am in a community

$\mathrm{Na}$

$\mathrm{Na}$

$\mathrm{Na}$

$\mathrm{Na}$

v

V

V

V 
19 , breastfeeding is necessary

If I am

suspected/infected with COVID-19, which needs to be recommended for cleanliness so I can breastfeed.

If I am confirmed suspect / infected COVID-19 does not have a medical mask, what remains to be breastfeeding.

If I am confirmed suspect / infected COVID-19, and can not breastfeed, what best breastmilk substitutes to meet the infant nutrition If I am confirmed suspect / infected COVID-19, otherwise provide breast milk to the baby in breast milk pumping, the steps I need to prepare to pump breast milk, breast milk storage containers, or infant feeding equipment. If I am confirmed suspect / infected COVID-19, nursing what can be replaced by other mothers in breastfeeding, or taking milk from the milk bank

If I am confirmed suspect / infected COVID-19 can not breastfeed due to being sick or have other diseases when the mother can start breastfeeding again Suggestions for breastmilk replacement during the pandemic COVID-19 are the main choice of formula milk

$\mathrm{Na} \quad \mathrm{Na}$

$\mathrm{Na}$

$\mathrm{Na}$

$\mathrm{Na}$

v

$\checkmark$

v

v

$\mathrm{Na}$

$\mathrm{Na}$

$\mathrm{Na}$

$\mathrm{Na}$

v

v

v

$\mathrm{Na}$

$\mathrm{Na}$

$\mathrm{Na}$

$\mathrm{Na}$

v

v

v

v

$\mathrm{Na}$

$\mathrm{Na}$

$\mathrm{Na}$

$\mathrm{Na}$

v

v

v

v

$\mathrm{Na}$

$\mathrm{Na}$

$\mathrm{Na}$

$\mathrm{Na}$

v

v

v

v

$\mathrm{Na}$

$\mathrm{Na}$

$\mathrm{Na}$

$\mathrm{Na}$

v

v

v

v

$\mathrm{Na}$

$\mathrm{Na}$

$\mathrm{Na}$

$\mathrm{Na}$

v

v

v

v

(C) Jurusan Keperawatan Poltekkes Kemenkes Jakarta I

Jl. Wijaya Kusuma No. 47-48 Cilandak Jakarta Selatan, Indonesia

Email: jurnalkpcardio@gmail.com 


\begin{tabular}{|c|c|c|c|c|c|c|c|c|}
\hline $\begin{array}{l}\text { I am afraid of } \\
\text { breastfeeding because } \\
\text { I have been } \\
\text { confirmed as being } \\
\text { suspicious / infected } \\
\text { with COVID-19 }\end{array}$ & $\mathrm{Na}$ & $\mathrm{Na}$ & $\mathrm{Na}$ & $\mathrm{Na}$ & $\mathrm{v}$ & $\mathrm{v}$ & $\mathrm{v}$ & $v$ \\
\hline $\begin{array}{l}\text { If I am confirmed } \\
\text { suspect / infected } \\
\text { COVID-19, my } \\
\text { choices replace breast } \\
\text { milk with formula } \\
\text { milk }\end{array}$ & $\mathrm{Na}$ & $\mathrm{Na}$ & $\mathrm{Na}$ & $\mathrm{Na}$ & $v$ & $\mathrm{v}$ & $\mathrm{v}$ & $v$ \\
\hline $\begin{array}{l}\text { The recommended } \\
\text { period for } \\
\text { breastfeeding again } \\
\text { when it has recovered } \\
\text { COVID-19 }\end{array}$ & $\mathrm{Na}$ & $\mathrm{Na}$ & $\mathrm{Na}$ & $\mathrm{Na}$ & $\mathrm{v}$ & $\mathrm{V}$ & $\mathrm{V}$ & $v$ \\
\hline $\begin{array}{l}\text { Reason differences of } \\
\text { social distancing are } \\
\text { recommended for } \\
\text { infants and mothers } \\
\text { who suspect / } \\
\text { infected COVID-19 } \\
\text { with the general } \\
\text { population }\end{array}$ & $\mathrm{Na}$ & $\mathrm{Na}$ & $\mathrm{Na}$ & $\mathrm{Na}$ & $\mathrm{v}$ & $\mathrm{v}$ & $\mathrm{v}$ & $v$ \\
\hline
\end{tabular}

Table 2 summarizes the results of research describing maternal information needs during the COVID-19 pandemic during pregnancy, childbirth, postpartum, and neonates. The information needs are clearly illustrated in the studies $5,6,7,8$. The information conveyed in the form of questions and maternal complaints related to COVID-19 in preventing limiting infections in themselves and their babies. In studies $1,2,3,4$ only some information can be obtained regarding maternal and fetal COVID-19 infections.

Table 2 shows that information needed by women giving birth includes the types of delivery for women suspected of COVID19 (normal or cesarean section), implementation of early breastfeeding initiation (IMD): skin to skin contacts, immediate breastfeeding for mother suspected Covid-19, and the risk of transmission of COVID-19 infection in newborns. Meanwhile, the health knowledge needed by postpartum mothers consist of the risks/benefits when touching and holding their babies, feeding options for newborns (breast milk or formula milk), risk of transmitting COVID-19 infection through breast milk, and the right time for mothers who have recovered from COVID19 to breastfeed their babies again. Also, the health education needed by the general people is related to the differences in the urgency of social distancing for the general population and mothers and infants.

\section{Discussion}


In general, the magnitude of the exposure risk to COVID-19 infection in the maternal or the community is the same. However, maternal conditions that are pregnant or have babies make the risk of infection worse. ${ }^{13}$ This happens because the mother and baby cannot be separated; therefore, the risk of infection becomes higher ${ }^{11,14}$. Symptoms of virus infections encountered by mothers during pregnancy are the same as those without pregnancy, specifically acute respiratory distress syndrome and anxiety. ${ }^{13,11}$ This is caused by respiratory distress syndrome and anxiety experienced by the maternal. These factors inhibit intravascular and intrauterine oxygen circulation, which stimulates increased blood pressure., ${ }^{2,5,15}$ Anxiety experienced during maternal exposure to virus infections stimulates the release of stress hormones triggering elevated blood pressure and initiating premature birth and early membrane rupture and preeclampsia. $^{15,16}$

The risk of pregnant women infected with COVID-19 is reviewed based on changes in the immune system of pregnant women. Previous information states that the immune system during pregnancy is good enough, but due to exposure to viral, bacterial, and parasitic infections, the mother's immunity is susceptible to infection. This occurs because of the suppression of immunity mediated by cells, due to changes in T helper one (Th1) cells to T helper two (Th2) cells. ${ }^{17}$ However, the morbidity and mortality of infected mothers vary between developed and developing countries. ${ }^{17,18}$ The severity and magnitude of the risk of infection for pregnant women depend on the geographical and demographic distribution.

These symptoms have an impact on the well-being of the mother and baby. However, the risk of death of the fetus/infant on the study case report not being infected COVID-19 from his mother but due to complications of pregnancy. 5,15,16 Based on the observed case report did not reveal any congenital defects after birth. This proves that the results of the COVID19 analysis with the RT-PCR test did not find SARS-COV2 in neonates. ${ }^{19,20}$ However, in neonatal blood serum samples detected an increase in the concentration of specific virus antibodies namely IgG which is transferred passively across the placenta from mother to fetus. ${ }^{19}$ Likewise in the placenta testing using RT-PCR technique, there was no SARS-COV2 virus. ${ }^{20}$ So that this study can be stated that SARS-COV 2 cannot damage the fetus during pregnancy and at birth if carried out by standard pandemic labor procedures.. ${ }^{19}$ The risk of 
COVID-19 infection for babies will be even greater after the baby is born so that after the baby is born it needs isolation and monitoring of the baby so it is not exposed to COVID-19. Infants are at risk of infection because they are exposed to the environment from health workers, parents, and other family members. ${ }^{19}$

But the existence of babies whose mothers can not be separated in a long time. The magnitude of the risk exposure is experienced neonatal infection, which can cause contact and maternal care to newborns reduced. Some health education that needs to be conveyed to mothers is the risk of infection, prevention of infection to baby, early contact, and breastfeeding. The principle that must be considered is to follow the standard infection control precautions (SICPs) and the transmissionbased precautions (TBPs) when they are suspected or confirmed of COVID-19. ${ }^{21}$ Infection prevention and control measures that need to be taken by the maternal are to reduce the risk of transmission from infectious agents through known and unknown sources. Sources of infection include blood and other bodily fluids, secretions and excretions (excluding sweat), incomplete skin or mucous membranes, and any equipment or items in the mothers' environments that are used by family members suspected of being infected with COVID-19. ${ }^{21}$
Early breastfeeding initiations $(I M D s)$ or skin-to-skin contacts and breastfeeding immediately after the babies are born in mothers suspected/infected with COVID19 need to be assessed in terms of its advantages and disadvantages. Newborn deaths are most often caused by hypothermia and hypoxia. ${ }^{7}$ Care of the babies immediately after birth by placing the baby with their mothers (roaming in), initiation of early breastfeeding and skin-toskin contacts, and care for kangaroo infants substantially outweigh the potential risks of transmission of COVID-19. ${ }^{7}$ These treatments can improve the temperature regulation of newborns and prevent hypoxia which has an impact on decreasing neonatal mortality. ${ }^{22}$

The choices of newborn food in the COVID-19 pandemic condition depend on socioeconomic conditions. Mothers with suspected/COVID-19 infection, when deciding to replace breast milk with formula milk, need to consider the ability to maintain the survival and development of the babies. ${ }^{9}$ Another thing to note is that the best choice for baby food is mothers' milk and breastfeeding itself improves maternal health. ${ }^{22}$ Until now, the transmission of COVID-19 through breast milk and breastfeeding has not been detected, hence there is any reason to avoid or stop breastfeeding. ${ }^{10}$ 
The technique of breastfeeding can be done in two ways, namely by pumping breast milk and breastfeeding. The pumping technique by hand or with a pump is in principle equally effective. It is important to note that mothers must wash their hands before expressing milk or touch a pump or bottle; that the pump must be washed every time after use; that breast milk should be given using clean cups and spoons; and medical masks must be used. ${ }^{14}$ Breast milk donors can be given if the mothers cannot express milk which is available at the ASI bank. For mothers who are seriously ill, donor breast milk is given to the babies until the mothers have begun to return to health. ${ }^{7}$ Mothers with symptoms of COVID-19 are advised to wear medical masks when breastfeeding. Prevention measures for infection while breastfeeding include washing hands; using medical masks; cleaning the nipple surface; and when sneezing or coughing, covering the mouth with the shoulders when not using masks. ${ }^{7}$ The use of non-medical masks (homemade masks or cloths) to date has not been evaluated in terms of prevention of the risk of transmission.

Differing views exist among national and professional organizations in terms of breastfeeding for mothers suspected/infected with COVID-19. The principle of the difference lies in the consideration of transmission of COVID19. WHO looks not only in terms of the risk of infection in infants but of the consideration of the morbidity and mortality associated with not breastfeeding and formula feeding. ${ }^{14}$ The process of breastfeeding provides a protective effect on the babies, increasing contacts between mothers and their babies. ${ }^{23}$

Likewise, pregnant women have concerns that fetus will become infected or not during labor. This was stated from a study of maternal complaints related to the impact of COVID-19 during delivery in several countries. The mother revealed the choice of the type of labor that will be undertaken in preventing transmission of infection to the neonate. In the labor phase, the type of labor in women who are suspected/infected with COVID-19 is adapted to the conditions of the mothers and babies. Surgery will only be performed if there is a medical indication. ${ }^{6}$ As stated in previous studies, the risk of COVID-19 infection in infants born to mothers exposed to the disease is small. This is consistent with observations of three cases of vaginal delivery in women exposed to COVID-19 in China i.e., the first case is preterm labor (35 weeks) with babies born fit and the SARS-COV-2 test results tested negative, 
the second case is mature births (39 weeks) with babies born to be fit. ${ }^{8}$ The results of the SARS-COV-2 test were negative, and the third case is three infants born mature (38 weeks) with a fit condition and the SARS-COV-2 test was negative. ${ }^{8}$

So its mother complained of a way to keep a distance between mother and baby. The treatment of maternal care with the babies suggests that there are differences in terms of social distancing measures as applied to the general population. The social distancing treatment of adults and children aims to reduce virus contact and transmission with asymptomatic people already infected with COVID-19. This program will reduce the prevalence of the general population infected with COVID-19 and more severe diseases. Social distancing is not applied to mothers and babies, because we regard the survival of the babies. ${ }^{7}$ The care and feeding of young children and infants with suspected/infected with COVID-19 mothers aim to improve the survival, health, and development of the newborns and children. This is recommended in regards to the possibility and potential risk of COVID-19 infection in infants and the risk of serious illness and death when the baby is not breastfed or when infant formula is used inappropriately. ${ }^{7,11}$ Other factors that become recommendations are the protective effects of breastfeeding and mother-baby contacts. Based on observations, children have a lower risk of COVID-19 infection. Several cases of COVID-19 infections are confirmed in children, but most of them have only had mild diseases or no symptoms. The many benefits of breastfeeding substantially outweigh the potential risks of transmission of COVID-19 infection, so social distancing does not apply to mothers and babies.

\section{Conclusion}

The current conclusions that need to be stated are that the risk of COVID-19 infection to the maternal, fetal / infant impacts on maternal, fetal / infant welfare. The most severe chances are death, preeclampsia, membrane rupture, premature birth, and low birth weight. The process of labor in conditions exposed to infection is through vaginal delivery so that the fetus not exposed to COVID-19. Thus, the search for maternal questions related to the COVID-19 pandemic is related to the information needs of maternal care and newborns. Maternal issues describe the feelings of worry and anxiety for her during pregnancy, childbirth, and the fetus/newborn. The information needed by the maternal during the COVID-19 pandemic can be concluded, including the process of viral infection, the type of delivery, breastfeeding, initiation of early 
breastfeeding, skin to skin contact, prevention of maternal to fetal infections, and social distancing. Such information can be provided through health education. hoped that during the COVID-19 pandemic, the maternal can take care of themselves, the fetus/baby, and reduce anxiety.

\section{Abbreviations}

COVID-19: Coronavirus Diseases 2019

SICPs: standard infection control precaution

TBPs: transmission-based precautions

Th1: T helper one cell

Th2: T helper two cells

IMD: inisiasi menyusui dini

ASI: air susu ibu

ABHR: alcohol-based hand rub (hand sanitizer)

ACE2: angiotensin-converting enzyme 2

\section{Acknowledgment}

The author appreciates the leadership of Jakarta Health Polytechnic 1, the Chairman of the Nursing Department who has facilitated the writing of this during work from the home period.

\section{References}

1. WHO. [homepage on the Internet]. United States of Amerika: Coronavirus disease (COVID-2019) situation reports; 2020 [updated 2020 Jan 1; cited 2020 May 1]. Available from: https://www.who.int/emergencies/dise ases/novel-coronavirus2019/situation-reports.

2. Hantoushzadeh S, Shamshirsaz AA, Aleyasin A, Seferovic MD, Aski SK, Arian SE, et al. Maternal Death Due to COVID-19 Disease. Am J Obstet Gynecol [serial on the Internet]. Apr 2020 [cited 2020 June 1]; 9378(8) [about 4 p]. Available from: https://doi.org/10.1016/j.ajog.2020.04. 030.

3. Sidhu S. [home page on the Internet]. New York: Pregnant mothers and babies born during COVID-19 pandemic threatened by strained health systems and disruptions in services; 2020 [updated 2020 April 2; cited 2020 June 5]. Available from: https://www.unicef.org/pressreleases/pregnant-mothers-and-babiesborn-during-covid-19-pandemicthreatened-strained-health.

4. Pritasari K. [homepage on the Internet]. Indonesia: DITJENKESMAS-Strategi-AkselerasiPenurunan-AKI-\&-BBLR; 2019 [updated 2019 Agust; cited 2019 Dec 1]. Available from: www.kesmas.kemkes.go.id. 
5. Royal College of Obstetricians and Gynaecologists. [homepage on Internet]. UK: RCOG and RCM respond to the UKOSS study of more than 400 pregnant women hospitalized with coronavirus [cited 2020 May 5]. Available from: https://www.rcog.org.uk/en/news/rcog -and-rcm-respond-to-ukoss-study-ofmore-than-400-pregnant-womenhospitalised-with-coronavirus/

6. Knight $\mathrm{M}$, Bunch $\mathrm{K}$, Vousden $\mathrm{N}$, Morris E, Simpson N, Gale C, et al. Characteristics and outcomes of pregnant women hospitalized with confirmed SARS-CoV-2 infection in the UK: a national cohort study using the UK Obstetric Surveillance System (UKOSS). National Perinatal Epidemiology [serial on the Internet]. May.; 2020 [cited 2020 June 6] . Available from: https://www.npeu.ox.ac.uk/downloads /files/ukoss/annual-reports/UKOSS COVID-19 Paper pre-print draft 1105-20.pdf.

7. Khan S, Peng L, Siddique R, Nabi G, Nawsherwan, Xue M, et al. Impact of COVID-19 infection on pregnancy outcomes and the risk of maternal-toneonatal intrapartum transmission of COVID-19 during natural birth. Infect Control Hosp Epidemiol [serial on the Internet]. May 2020 [2020 June 5];1-3.
Available

from:

https://doi.10.1017/ice.2020.84.

8. Chen H, Guo U, Wang H, Fan Luo XY, Zhang W, Li J, et al. Clinical characteristics and intrauterine vertical transmission potential of COVID-19 infection in nine pregnant women. Lancet [serial on the Internet]. June 2020 [cited 2020 June 5]; 395:809-15. Available from: https://doi.org/10.1016/ S01406736(20)30360-3.

9. WHO. [homepage on the Internet]. Indonesia: Pertanyaan jawaban terkait COVID-19 untuk ibu hamil dan melahirkan; 2020 [updated May 2020; cited 2020 May 5]. Available from: https://www.who.int/indonesia/news/n ovel-coronavirus/qa-duringpregnancy.

10. Hollier L. [homepage on the Internet]. Texas The American College of Obstetricians and Gynecologists (ACOG): Coronavirus (COVID-19), Pregnancy, and Breastfeeding: A Message for Patients; 2020. [updated 2020 June 1; cited 2020 June 5].; Available from https://www.acog.org/patientresources/faqs/pregnancy/coronaviruspregnancy-and-breastfeeding.

11. RCOG.[homepage on the Internet]. London: Coronavirus infection and pregnancy; 2020 [updated May 2020; 
cited 2020 May 5]. Available from:

https://www.rcog.org.uk/en/guidelines

-research-

services/guidelines/coronavirus-

pregnancy/covid-19-virus-infection-

and-pregnancy/.

12. World Health Organization (WHO). [homepage on the Internet]. Q\&A Pregnancy, childbirth, and COVID-19 [updated 2020 March 18; cited 2020 May 5]. Available from: https://www.who.int/emergencies/dise ases/novel-coronavirus-2019/questionand-answers-hub/q-a-detail/q-a-oncovid-19-pregnancy-and-childbirth.

13. Miller SE, Grobman AW, Sakowicz, A, Rosati J, Peaceman MA. Clinical Implications of universal severe acute respiratory syndrome coronavirus 2 (SARS-CoV-2) testing in pregnancy. Obstetrics \& Gynecology. [serial on the Internet]. May 2020 [cited 2020 June 29]. Availablehttps://journals.lww.com/gre enjournal/pages/articleviewer.aspx?ye ar $=9000 \&$ issue $=00000 \&$ article $=97343$ $\&$ type $=$ Citation .

14. World Health Organisation. [homepage on the Internet]. WHO:.Breastfeeding and COVID-19 for health workers: frequently asked questions; 2020 [updated 2020 March 13; cited 2020
May 1]. p. 1-3. Available from: www.who.int/publicationsdetail/clinical-management-of-severeacute-.

15. Kwon JY, Romero R, Mor G. New insights into the relationship between viral infection and pregnancy complications. Am J Reprod Immunol. [serial on the Internet]. May 2014 [cited 2020 June 29]; 71(5): 387-390. Available

https://www.ncbi.nlm.nih.gov/pmc/art icles/PMC 5891092 /pdf/nihms $954256 . p d f$.

16. Abbas MA, Ahmed AO, Shaltout SA. COVID-19, and maternal preeclampsia; a synopsis. Immunology. [serial on the Internet]. 15 June 2020. [cited 2020 June 29]. Available https://onlinelibrary.wiley.com/doi/abs /10.1111/sji.12918.

17. Morelli S, Mandal M, Goldsmith LT, Kashani BN, Ponzio NM. The maternal immune system during pregnancy and its influence on fetal development. Res Rep Biol. [serial on the Internet]. Oct 2015 [cited 2020 May 2];171. Available http://dx.doi.org/10.2147/rrb.s80652.

18.Stein D, Ward K, Cantelmo C. Estimating the Potential Impact of COVID-19 on Mothers and Newborns

(C) Jurusan Keperawatan Poltekkes Kemenkes Jakarta I

Jl. Wijaya Kusuma No. 47-48 Cilandak Jakarta Selatan, Indonesia

Email: jurnalkpcardio@gmail.com 
in Low- and Middle-Income Countries.

Health Policy Plus. [serial on the Internet]. May 2020 [cited 2020 May 1]. [about 2 p]. Available from: http://www.healthpolicyplus.com/covi d-mnh-impacts.cfm.

19. Hubei, Liu C, Yan T G. (2020) Antibodies in infants born to mothers with COVID-19 pneumonia. JAMA [serial on the Internet]. May 12, 2020 [cited 2020 July 8 ]; 323(18): p.18481849. Available from: https://jamanetwork.com/ on 07/07/2020.

20. Egloff C, Fellous V C, Picone O, Mandelbrot L, Roque P. Evidence and possible mechanisms of rare maternalfetal transmission of SARS-CoV-2. Journal of Clinical Virology [serial on the Internet]. 14 May 2020. [cited 2020 July 1]; p.1-9. Available from: https://doi.org/10.1016/j.jcv.2020.104 $\underline{447}$.

21. Public Health England. COVID-19: infection prevention and control guidance. PHE publications [serial on the Internet] March 2020. [cited 2020 May 3] [about 1-62 p] Available from: 